\title{
Correlation of Learning Method of Prophetic Character Education toward Student Achievement Learning Outcomes in Vocational Education in Indonesia
}

\author{
Ishomuddin* \\ Professor Dr., Faculty of Islamic Education, University of Muhammadiyah Malang, Indonesia \\ *Corresponding Author: Ishomuddin , Professor Dr., Faculty of Islamic Education, University of \\ Muhammadiyah Malang, Indonesia.ummishom@gmail.com
}

\begin{abstract}
This study aims to clarify the relationship between learning methods prophetic character education with student achievement in the field of character education in schools. This study uses a quantitative approach with a statistical formula Product Moment. Collecting data in this study using observations, questionnaires and documentation. In practice, the researchers conducted a study on the learning process in the classroom related to the way teachers teach or methods used in educational subjects prophetic character. Pembejaran and curriculum materials have been determined by the school institution. Determined with a random sample of the population that has been quantified. After the learning process by using certain methods at the end of the semester and then held a test. The test results connected using Product Moment correlation statistical tests, the results are as follows: there is a correlation between the prophetic character education learning method with the results for students at the school with a degree of correlation is very strong.
\end{abstract}

Keywords: Correlation, Method, Learning, Character, Education, Achievement, Vocational Education

\section{INTRODUCTION}

Character education is a concern to many countries in order to prepare the next generation of quality, not only for the benefit of individual citizens, but also for members of the community as a whole. Character education can be defined as the deliberate us of all dimensions of school life to foster optimal development character (we deliberate effort of the whole dimension of the life of the school/ madrasah to help the formation of character optimally).

Strengthening moral education or character education is very relevant in the present context to address the moral crisis that hit in various countries including Indonesia. Such crisis in the form of increased promiscuity, rampant levels of violence children and adolescents, crimes against friends, deviations moral teens, the habit of cheating, drug abuse, pornography, and the destruction of property of others, has become a social problem today cannot be completely resolved.

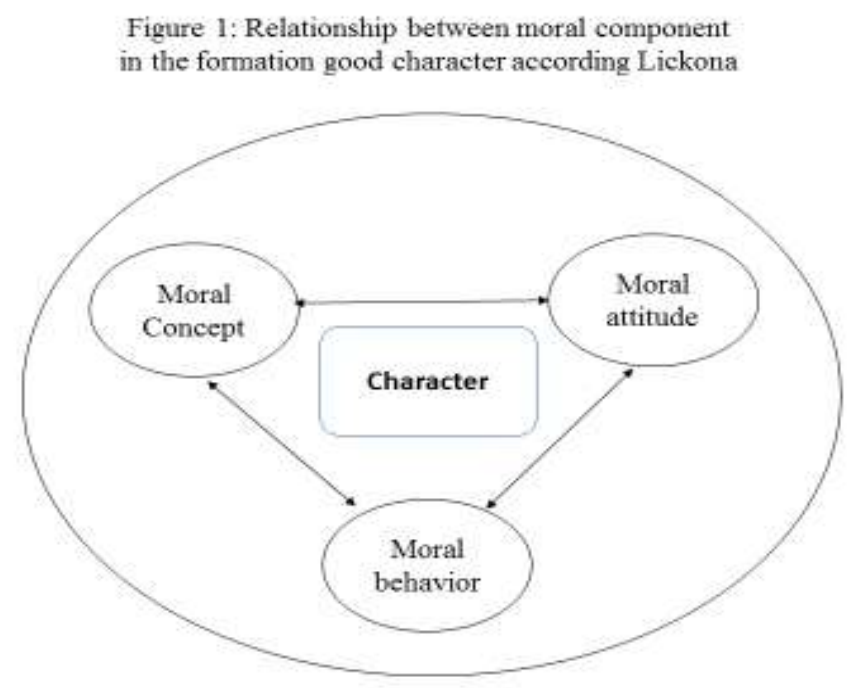


According Lickona, characters related to the concept of moral (moral knonwing), moral attitudes (moral felling), and moral behavior (moral behavior). Based on these three components can be stated that good character is supported by the knowledge of the good, the desire to do good, and do deeds of kindness. Outlined below is a chart of the third link this framework.

Simply put, the character education can be defined as any attempt to do to influence the character of the students. But to know the proper sense, it can be argued that the definition proposed by Thomas Lickona. Lickona stated that the definition of character education is a deliberate attempt to help someone so that he can understand, pay attention, and do the ethical values that core. Suyanto (2009) defines the character as a way of thinking and behaving that is characteristic of each individual to live and work together, both within the family, community, nation, and state. Characters are typically owned by an object or individual. The distinctive feature is the original and rooted in the personality or the individual objects, as well as an "engine" that drives how an act, behave, say, and respond to something. According to the dictionary of psychology, personality character is to be reviewed from the standpoint of ethical or moral, for example a person's honesty, and is usually associated with the properties that are relatively fixed. There are 18 grain values of character education is, Religious, Honest, Tolerance, Discipline, Work Hard, Creative, Independent, Democratic, Curiosity, Excitement Nationality, Love the motherland, Rewarding achievements, Friendly/communicative, Love Peace, Joy of reading, Care for the environment, social Care and responsibility.

The study was conducted to test whether there is a relationship between learning methods prophetic character with values achievement in character education and changes the character of the students at the Vocational education in Indonesia.

\section{Prophetic Character Education}

Education is an important factor in development in every state. AzyumardiAzra (2008) linking education with culture and religion as a force for learners of value investment. Education in addition to covering the transfer and transmission of knowledge is also a strategic process to instill values in order civilizing children. In the meantime, religion also contains the doctrine of nobility and honorable for a man to achieve human dignity and culture. However, in certain times of the three sources of value cannot fully function in the formation of individual and community character and civilized.

ArmaiArief (2008) supports three sources of these values can be shaped the character of the nation. In an effort to character development of the nation through a cultural approach, all three have a close relationship and direct contact, even inseparable from public life. Academics give special attention to the education of character. Study striking human character is very complicated because it involves many scientific disciplines. When humans behave then we know the discipline of anthropology that is concerned to learn about humans. When talking about human behavior good and bad then we are talking about moral discipline, ethics. Similarly with psychiatric problems who gave birth to act then we learn the disciplines of psychology. When talking about the interaction of the community then we study sociology.

H.A.R Tilaar (2008) in the "National Character in Contemporary Pedagogical Perspectives" suggests several meanings of the term character. The term character or characters in the Indonesian language is often translated with the character, the true nature of a person or a group or a nation. However, the term character shall have the meanings that are very diverse, including the following: (1) character means the identity of someone who encompasses the whole attitude/behavior that can be recognized in a variety of situations, (2) In a narrow sense the character is a trait or characteristic of someone who is very prominent so is a trade mark of the person, (3) When we hear the phrase as follows: "Oh, it was already his character". This means that the behavior is the result of someone else's work depicts certain personal qualities possessed by a person, (4) The phrase "the movie player is the player character" can also be referred to as a player character. Or the phrase "strong personal Kublai Khan was played by the player character is right", (5) The letters in the alphabet also called character, and (6) The symbols used in computers also called character.

If we consider the meaning of the terms of the above characters, then the first, we see the ethical charge in that character. Second, the character is a personal belonging of a person or a community or a 
nation. By using glasses ethical and personal values that we would interpret the "character" as belonging to human beings. Simon Philips revealed that the character is a collection of values that lead to a system, which underlies a thought, attitudes and behaviors that are displayed. DoniKusuma argued that the character is personality.

Personality regarded as characteristic or characteristics or style, the distinctive nature of a person who comes from formations received from the environment. Explaining the meaning of the character of both etymologically and terms mainly of experts will find different meanings depending on the perspective, scientific fields owned and method of approach is taken, but all of them lead to the discussion of human beings as a better individual and social. This is where the prophetic role to internalize the values into character education. Basically, character education is to speak of the potential that exists in man. Humans have the potential physical, mind and heart, prophetic education should be able to exploit the potential of this three.

If the sense code suggested by experts over the character is personality, behavior, or values that underlie human behavior then we just add only that it can refer to the human character plenary (the prophet). Because education does not approve the prophetic model of education that only emphasizes the intellectual progress, cognition and memorization.

Therefore, any educational concept created, education should be directed to the purpose of man's worship in order to carry out the mission of God. Prophetic educational concept becomes important in order to save humanity from western hegemony understanding that can lead to dehumanization. If we assume a human robot, the robot batteries or electricity from the electric current that is prophetic and God holder of the remote control. Prophetic religious values in the education space that must be our present and reflected in the implementation of a prophetic figure as a model.

There are two variables behind the idea of prophetic character education in this research. The first is character education. The emergence of the idea of character education is a response to the failure of the education that produces human beings in accordance with the moral and national identity and religion. Educational institutions only managed to score a man who memorized the lesson, the smart answer the question, dishonest thus obtained only academic values without a moral-ethical values. However, this idea like a double-edged sword, on the one hand a noble mission to shape human character but on the other hand the education system still uses the classic rule of law. Evaluation of education to learners only emphasizes the intellectual aspect, the learning center teacher and "go-child point is" emotional and spiritual capabilities is the fact the public is not in accordance with the vision of the character education itself. Education is supposed to liberate humanity from the problems of life even imprisoned by the education system itself. True character education as a container exemption that free people from ignorance, oppression and poverty for the nation in the form of intelligent life oppression.

Second, Prophetic Character. Prophetic character is spirits that fortify the education of various negative excess that comes as a result of the globalization in the era of modernity. Seeing the world phenomenon now, Max Weber (1958) in a thesis saying that we live in a universe marked by rationalization and intellectual. The world is no longer a sacred phenomenon, life is no longer a mystery that cannot be predicted. The fate of man is no longer in the hands of superhuman. Religion at a time conspire with human progress is not needed anymore. Protestantism facilitate the development of capitalism, but now based on a foundation of victorious Protestantism is mechanical and no longer need the support of religion. How Weber saw the reality of life is getting away from the values of humanity, transcendental moral grounding not only the return of the promise of peace. This is because the greater the distance the human with the sacred values-religious. The question is, who will develop the climate that has been distorted in a climate that has a foundation of ethical values and moral-transcendental, so that life can return to reveal his true face, the face of humanity? Because the process of westernization has penetrated into the joints of education from the primary level to the college level. Cary Nelson stated that the dangers to the university of the 21st century, namely (1) the corporatization/neoliberalism education, (2) instrumentalism: education, including higher education do not have ideals, but only becomes an instrument for profit, and (3) the threat of neoliberalism to discipline academic. 
Cary Nelson Concerns have already occurred in the Indonesian nation with empirical evidence that the product is a graduate employable education but weak soft skills. The view of the graduate college "high competence" is a graduate with a high GPA and pass in a short time (4 years). While the industry stated that the definition of graduates that "high competence" ie those who have skills in the technical aspect and a good attitude. (IllahSailah, 2008). Therefore, a person's good behavior is one of them had emotional intelligence, has a dominant role in determining the success of a person's life. This is in accordance with the opinion of Daniel Goleman about the success of someone that, it turns out 80 percent influenced by emotional intelligence, and only 20 percent is determined by the intelligence (IQ). Bachelor who was born in the era of reform generally more pragmatic and experienced "emptiness intellect". They became apathetic about community conditions and the experience of stuttering when talking broader topics. In the absence of social skills, the provision of hard skills and soft skills, they just become a human being robotic.

Prophetic education is social engineering as an alternative solution of anxiety educational walk without a clear spirit. Zamroni in his paper entitled "The role of social studies in the context of nation and character building" stated that: character does not automatically develop in themselves citizens of the nation or learners. There needs to be social engineering designed and implemented consciously with a clear direction. Social engineering is increasingly important, because the multidimensional character of which is the participation of various school/educational institution independently will not be able to develop character among learners. Social engineering to character development should be planned and implemented as thoroughly and accurately as possible. In this case, the prophetic character education can perform social engineering such collaborations transcendental spiritual values with the unique culture of the nation involving educational institutions, the family and society in order to achieve educational goals.

\section{LEARNING METHODS}

Method of teaching is the study of ways to perform the activity which is a system of an environment consisting of educators and learners to interact with each other in doing an activity so that the learning goes well in terms of teaching objectives achieved.

To be achieved in accordance with the teaching objectives that have been formulated by educators, it is necessary to know to learn some methods of teaching, and teaching is practiced at the time. Some methods used include (1) Method Lecture (Preaching Method). The lecture method is a method of teaching by means of conveying information and knowledge is lacking spoken to a number of students (Muhibbin Shah, 2000). Lecture method can be considered as the only method that is most economical to convey information, and the most effective in addressing the scarcity of literature or appropriate referral to reach and understand students' purchasing power, (2) method of discussion (Discussion method). Discussion method is a method of teaching that is closely related to solving problems (problem solving). This method is also commonly referred to as a group discussion (group discussion) and recitation together (socialized recitation), (3) methods of demonstration (Demonstration method). Demonstration method is a method of teaching by way of demonstrating goods, events, rules, and the order to perform an activity, either directly or through the use of teaching aids relevant to the subject or the material being presented (Muhibbin Shah, 2000). Demonstration method is a method used to show something processes or the workings of an object with respect to the subject matter (Saiful BahriDjamarah, 2000), (5) The method of recitation (Recitation method). Recitation method is a method of teaching in which students are required to make a resume with their own sentences.

\section{Factors Affecting Results of Study}

Doing the analysis is the cornerstone of finding the problems that occur in learning activities. Learning is a process toward a goal that has been planned. Every individual has the distinction of achieving learning outcomes. The differences are related to the factors that influence it. Areas of learning outcomes can be divided into two parts: internal and external factors. Purwanto (2013) says there are two factors of learning outcomes, as follows: 
Figure 2. Areas of learning outcomes

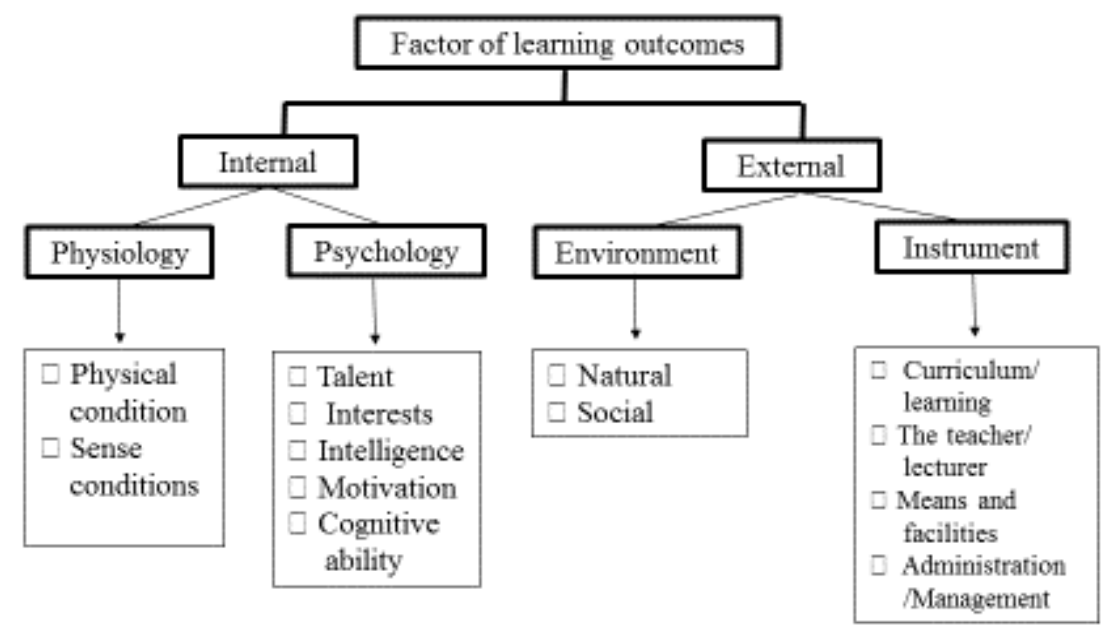

\section{MeThodology}

\subsection{Research Approach}

Associated with the formulation of the problem posed, this research using quantitative approach, namely the study of the numbers and using statistical analysis (Sugiyono, 2014). This study was a correlation study is research relating to the collection of data to determine whether there is any relationship between variables or more and at what level of relationship (Sumanto, 1990).

\subsection{Research Goals}

Goal of this study is addressed to students of vocational schools in some schools in Indonesia. Targets have been selected for the vocational education is the most important educational and determine a student's life before proceeding to higher education or university.

\subsection{Research Variable}

The scope of this study includes two variables, namely the independent variables and the dependent variable. According Sugioyono (2014), the independent variable is the variable that is often called the stimulus variables, predictor, antecedent. In the Indonesian language is often called the independent variable is the variable that affects or is the cause of the change or the emergence of the dependent variable (dependent). While the dependent variable is often called a variable output, criteria, consequently. In the Indonesian language is often called the dependent variable is the variable that is affected or which become due for their independent variables.

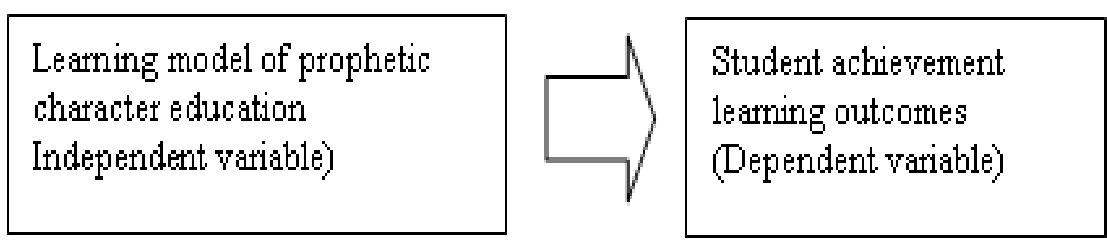

Figure 2. Relationship Independent and Dependent Variables

\subsection{Research Hypothesis}

In this study, there are two hypotheses to be tested, the Zero hypothesis (Ho) and alternative hypothesis (Ha).

\section{a) Zero Hypothesis}

Ho: There is no correlation learning method prophetic character education to achievement in school.

Alternative Hypothesis

Ha: There is a correlation prophetic character education learning methods to achievement in school. 


\section{b) Statistical Hypotheses}

Ho: $\rho=0,0$ indicates no relationship

Ha: $\rho=0$, "not zero" means greater than or less (-) of zero means no relationship, $\rho=$ correlation value in the formulation of the hypothesized correlation exists prophetic character education learning model to achievement in school

\subsection{Population}

Population is the generalization region consisting of the object/subject that has certain qualities and characteristics defined by the researchers to learn and then drawn conclusions. The population in this study were students in vocational education amounted to some 46 students.

\subsection{Samples}

The sample is part of the number and characteristics of being owned by the population. The sample in this study were students in vocational education..The strategy of sampling in this research using random sampling technique, which is taking a random member of the population sample. Researchers took samples from a population of 39 students.

\subsection{Research Instruments}

Research instrument is a tool used in research to measure variables. In this research there are two variables, namely the implementation of character education or learning methods prophetic and religious achievement scores. Instruments to reveal prophetic character education is learning to use the technique achievement test, the test results of study that aims to determine the ability of students to material that has been studied. Tests given in the form of multiple choice questions (multiple choice). In the variable value educational achievement prophetic character, the instrument used is to use documentation techniques, which collects data such as the results of the report cards of students in each school.

\subsection{Data Collection Technique}

Data collection techniques used by the author in obtaining accurate data is to use interview techniques, documentation and testing.

\subsection{Interview}

The interview is a tool to gather information by asking a few questions asked orally and answered orally (Zuriah, 2006). This interview technique used to obtain information about students on vocational education on all things related to the data studied.

\subsection{Documentation}

Documentation is a technique of collecting data by collecting and analyzing documents, both written documents, images, and electronic media. The essence of this documentation technique is a method used to browse through historical data (Bungin, 2005). The documentation in this study a school profile, the number of students, the results of students in the school report cards each.

\subsection{Test}

The tests are tools used in measurement and assessment systematically arranged in which there are a variety of questions or a series of tasks to be done (Arifin, 2009). In this study, researchers used a test of learning outcomes in the form of multiple choice (multiple-choice).

\subsection{Data analysis}

According to Julia Branen, data analysis is the processing and interpretation of data with a series of activities of study, grouping, systematic, interpretation, and Verification of data that a phenomenon has a value in social, academic, and scientific (in Munawaroh, 2006). In the analysis of this data, researchers used statistical data analysis, this is because the data collected in the form of quantitative data. Koentjaraningrat (1989) says that analysis of data are the data stage is done and used to deduce the truth that is used to answer questions posed in the study. Quantitative data analysis also called static analysis that the process can be divided into three phases: preliminary (data processing), the stage of organizing data, and the results of the discovery phase.

In this study the authors analyzed the data using the formula Product-Moment Correlation (Pearson) is one of the correlation technique that is often used to find the correlation between the two variables. Product-Moment Correlation Known as the correlation coefficient obtained by multiplying the 
Correlation of Learning Method of Prophetic Character Education toward Student Achievement Learning Outcomes in Vocational Education in Indonesia

moments variables are correlated. The correlation coefficient expressed as a number between 0 to +1 , or 0 to -1 . The correlation coefficient ( $\mathrm{r}$ ) approaches +1 or -1 means that there is a strong relationship, and vice versa if it is close to 0 (zero) means a weak correlation relationship, or no relationship. If the correlation (r) is equal to +1 or -1 means that there is a positive relationship is perfect, or perfect negative correlation. To calculate the correlation coefficient (r) Product-Moment Pearson, use the following formula:

$$
r_{\mathrm{xy}}=\frac{\sum \mathrm{X}_{1} \mathrm{X}_{2}-\left(\sum \mathrm{X}_{1}\right)\left(\sum \mathrm{X}_{2}\right)}{\sqrt{ }\left[\left(\mathrm{N} \sum \mathrm{X}_{1}^{2}-\left(\sum \mathrm{X}_{1}\right)^{2}\right]\left[\mathrm{N} \sum \mathrm{X}_{2}^{2}-\left(\sum \mathrm{X}_{2}\right)^{2}\right]\right.}
$$

Where

$$
\begin{array}{ll}
r_{\mathrm{xy}} & =\text { Digit product-moment correlation index } \\
\mathrm{N} & =\text { Number of cases } \\
\sum \mathrm{X}_{1} \mathrm{X}_{2} & =\text { Number of the result of multiplying X1 and X2 } \\
\sum \mathrm{X}_{1} & =\text { The total score } \mathrm{X} 1 \\
\sum \mathrm{X}_{2} & =\text { The total score } \mathrm{X} 2
\end{array}
$$

\section{FINDINGS}

In this study, researchers used quantitative methods, so the researchers used data analysis techniques

\begin{tabular}{|c|c|c|c|}
\hline No. & Name & Test of Learning Outcomes $\left(\mathrm{X}_{1}\right)$ & $\begin{array}{c}\text { Learning outcomes of educational } \\
\text { religious character }\left(\mathrm{X}_{2}\right)\end{array}$ \\
\hline 1. & Student A & 72 & 78 \\
\hline 2. & Student B & 76 & 80 \\
\hline 3. & Student C & 66 & 78 \\
\hline 4. & Student D & 64 & 85 \\
\hline 5. & Student E & 68 & 71 \\
\hline 6. & Student F & 76 & 82 \\
\hline 7. & Student G & 72 & 72 \\
\hline 8. & Student H & 62 & 85 \\
\hline 9 & Student I & 52 & 90 \\
\hline 10. & Student J & 32 & 90 \\
\hline 11. & Student K & 82 & 90 \\
\hline 12. & Student L & 70 & 86 \\
\hline 13. & Student M & 78 & 90 \\
\hline 14. & Student N & 80 & 100 \\
\hline 15. & Student O & 68 & 84 \\
\hline 16. & Student P & 70 & 76 \\
\hline 17. & Student Q & 78 & 80 \\
\hline 18. & Student R & 78 & 86 \\
\hline 19. & Student S & 76 & 85 \\
\hline 20. & Student T & 88 & 87 \\
\hline 21. & Student U & 80 & 84 \\
\hline 22. & Student V & 74 & 86 \\
\hline 23. & Student W & 90 & 86 \\
\hline 24. & Student X & 82 & 86 \\
\hline 25. & Student Y & 80 & 80 \\
\hline 26. & Student Z & 74 & 80 \\
\hline 27. & Student AA & 76 & 87 \\
\hline
\end{tabular}
using the formula Pearson Product-Moment to prove the relationship prophetic character education learning model to achievement and change the character of the students. Presentation of data in the form of test results to student learning by providing totaling about 50 questions associated with prophetic character education. Meanwhile, to obtain data on student learning outcomes, the researchers took the value of the subject of character education students the second semester of 20152016. The result can be seen in the following table:

Tabel 1. Value data of test results learning character education of students in Vocational Education 
Correlation of Learning Method of Prophetic Character Education toward Student Achievement Learning Outcomes in Vocational Education in Indonesia

\begin{tabular}{|l|l|l|l|}
\hline 28. & Student BB & 70 & 84 \\
\hline 29. & Student CC & 80 & 78 \\
\hline
\end{tabular}

According to the table above, in analyzing it can be demonstrated as follows:

Tabel 2. Value data of test results learning character education of students in Vocational Education

\begin{tabular}{|c|c|c|c|c|c|}
\hline No. & $\begin{array}{c}\text { Test of } \\
\text { Learning } \\
\text { Outcomes } \\
\left(\mathrm{X}_{1}\right)\end{array}$ & $\begin{array}{l}\text { Learning outcomes of } \\
\text { educational religious } \\
\text { character }\left(\mathrm{X}_{2}\right)\end{array}$ & $\mathrm{X}_{1}^{2}$ & $X_{2}^{2}$ & $\mathrm{X}_{1} \mathrm{X}_{2}$ \\
\hline 1 & 90 & 100 & 8100 & 10000 & 9000 \\
\hline 2 & 88 & 90 & 7744 & 8100 & 7920 \\
\hline 3 & 82 & 90 & 6724 & 8100 & 7380 \\
\hline 4 & 82 & 90 & 6724 & 8100 & 7380 \\
\hline 5 & 80 & 90 & 6400 & 8100 & 7200 \\
\hline 6 & 80 & 87 & 6400 & 7569 & 6960 \\
\hline 7 & 80 & 87 & 6400 & 7569 & 6960 \\
\hline 8 & 80 & 86 & 6400 & 7396 & 6880 \\
\hline 9 & 78 & 86 & 6084 & 7396 & 6708 \\
\hline 10 & 78 & 86 & 6084 & 7396 & 6708 \\
\hline 11 & 78 & 86 & 6084 & 7396 & 6708 \\
\hline 12 & 76 & 86 & 5776 & 7396 & 6536 \\
\hline 13 & 76 & 85 & 5776 & 7225 & 6460 \\
\hline 14 & 76 & 85 & 5776 & 7225 & 6460 \\
\hline 15 & 76 & 85 & 5776 & 7225 & 6460 \\
\hline 16 & 74 & 84 & 5476 & 7056 & 6216 \\
\hline 17 & 74 & 84 & 5476 & 7056 & 6216 \\
\hline 18 & 72 & 84 & 5184 & 7056 & 6048 \\
\hline 19 & 72 & 82 & 5184 & 6724 & 5904 \\
\hline 20 & 70 & 80 & 4900 & 6400 & 5600 \\
\hline 21 & 70 & 80 & 4900 & 6400 & 5600 \\
\hline 22 & 70 & 80 & 4900 & 6400 & 5600 \\
\hline 23 & 68 & 80 & 4624 & 6400 & 5440 \\
\hline 24 & 68 & 78 & 4624 & 6084 & 5304 \\
\hline 25 & 66 & 78 & 4356 & 6084 & 5148 \\
\hline 26 & 64 & 78 & 4096 & 6084 & 4992 \\
\hline 27 & 62 & 76 & 3844 & 5776 & 4712 \\
\hline 28 & 52 & 72 & 2704 & 5184 & 3744 \\
\hline 29 & 32 & 71 & 1024 & 5041 & 2272 \\
\hline & $\sum X_{1=} 2114$ & $\sum \mathrm{X}_{2}=2426$ & $X_{1}^{2=} 157540$ & $2^{2}=203938$ & $X_{2}=17$ \\
\hline
\end{tabular}

To search Product Moment Correlation Coefficient, then calculated using the following formula:

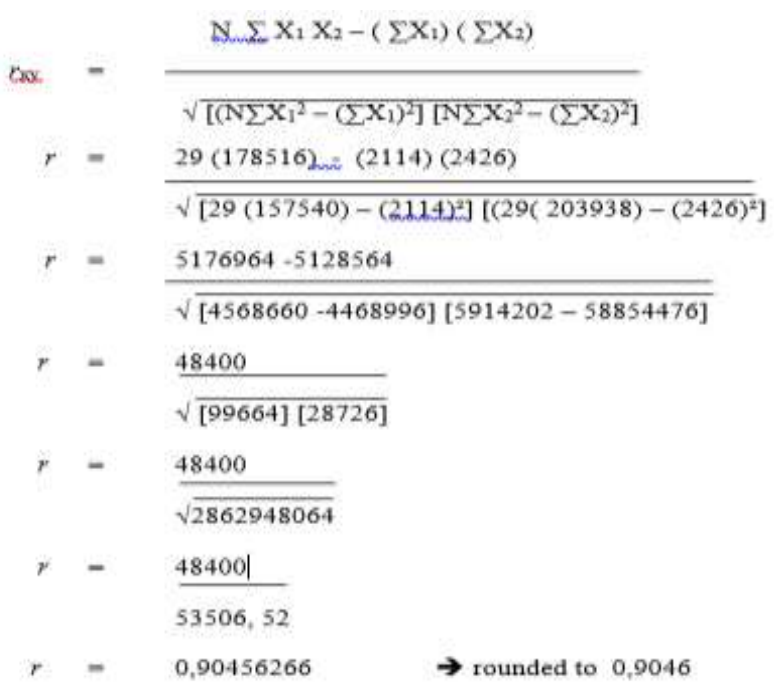


To test the correlation coefficient (r) product moment, then the tables associated with product moment correlation (r-table).

But previously had sought independent degrees $(\mathrm{db})$.

Formula looking $\mathrm{db}=\mathrm{N}-1$; for $\mathrm{N}=29$, then $\mathrm{db}=29-1=28$.

In the r-table with a significance level of $5 \%$ and $1 \%$ against $\mathrm{db}=28$ respectively are 0.374 and 0.478 , then we can count comparison between r-r-table.

The results show $r$-count $=0.9046$; and r-table $=0.0478(1 \%)$ and $0.374(5 \%)$.

Seen that, both with significance level $\alpha=0.05$ or $\alpha=0.01$;

Price-count $r>$ r-table.

In testing the hypothesis, to consider the following criteria:

- Hipotesis H0, when the count $r<r$-table

- Hipotesis H0, when the r-count> r-table

Because $r$ the above calculation was greater than the price of $r$ table, then $\mathrm{H} 0$ is rejected. This means, that $\mathrm{Ha}$ is received, which is a significant relationship between education learning method prophetic character to character education learning outcomes of students in vocational education. Then, to provide interpretation of the correlation coefficient is big or small, can be guided by the provisions of raw listed in the following table:

Tabel 3. Interpretation of Correlation Coefficient

\begin{tabular}{|l|l|}
\hline \multicolumn{1}{|c|}{ Interval Coefficient } & \multicolumn{1}{c|}{ Degree of Correlation } \\
\hline $0,00-0,199$ & Very low \\
\hline $0,20-0,399$ & Low \\
\hline $0,40-0,599$ & moderate \\
\hline $0,60-0,799$ & Strong \\
\hline $0,80-1,00$ & Very strong \\
\hline
\end{tabular}

Test statistics produce prices r-count magnitude of 0.9046, then the degree of correlation between variables prophetic teaching character education to student learning outcomes in vocational education with a degree of correlation is very strong. So it can be seen that:

- Price r-count: 0.9046

- At the significance level of $5 \%$ and $1 \%$ against $\mathrm{db}=28$; r-table $=0.0478(1 \%)$ and $0.374(5 \%)$; price-count $r>r$-table

Based on the description and analysis of the above data the researcher can interpret as follows:

- There is a very strong correlation between the prophetic character education teaching methods to the learning outcomes of students in the school. This is shown by the price of $r$-count obtained by (0.9046) greater than the price obtained by the table r- price $=0.0478(1 \%)$ and $0.374(5 \%)$.

- With more magnitude $\mathrm{r} r$ count of the table is at the level of $1 \%$ and 5\%, which is the alternative hypothesis (Ha) accepted that: "There is a correlation learning method prophetic character of the value of character education achievement in school" and vice versa nil hypothesis (Ho) be denied that No correlation method prophetic character education to the value of character education achievement of students in vocational education.

\section{DISCUSSION AND CONCLUSION}

Based on the results of a statistical test by using product moment correlation test, the result, that there is a relationship (correlation) is very strong between the prophetic character education teaching methods to the learning outcomes and changes the character education of students in the school. The results of the study can theoretically explained that the determining factors that influence learning 
outcomes are internal and external factors. Internal prophetic character education including external factors instrumental in the curriculum / materials. This is because that the teaching material in schools is almost as though the material at each grade level is not the same between.

Based on the analysis and discussion of the data gathered from research on "Correlation of Learning Method of Prophetic Character Education toward Student Achievement in Vocational Education Learning Outcomes" can conclude that there is a correlation between the prophetic character education learning method with the results for students at the school with a degree of correlation is very strong

It is based on statistical analysis using product moment correlation test which resulted in price-count result $r=0.9046$; and $r$-table $=0.0478(1 \%)$ and $0.374(5 \%)$. So that the $r$ count is greater than $r$ table with hypothesis testing criteria as follows:

Hipotesis H0, when the count $\mathrm{r}<\mathrm{r}$-table

Hipotesis H0, when the r-count> r-table

The existence of a very strong correlation between educational methods prophetic character to character education achievement of learning outcomes of students in vocational education. This is shown by the price of r-count obtained by $(0.9046)$ is greater than the price of r-tables were obtained at a price $=0.0478(1 \%)$ and $0.374(5 \%)$.

Thus it can be understood that the prophetic character education methods have relationships that can improve student learning outcomes in schools on vocational education.

Success in learning outcomes derived from internal and external factors. Talent, enthusiasm, intelligence, motivation and the environment is also one factor that can improve student learning outcomes themselves. With the curriculum/learning materials, teacher, tools, facilities and administration/management is also a factor of success of learning outcomes. Thus, the prophetic character education learning methods encourage achievements in character education in schools on vocational education.

\section{REFERENCES}

[1] Arief, Armai. PengantarIlmudanMetodologi Pendidikan Islam. Jakarta: CiputatPers, 2002

[2] Arifin, Zaenal. EvaluasiPembelajaran: Prinsip Teknik Prosedur. Bandung: PT. RemajaRosdakarya, 2009

[3] Azra, Azyumardi, Pendidikan Karakter: PeranGerakanPerempuan, http://www.findtoyou.co.id /docum nt/get/SyzD666D/pendidikan karakterperangerakanperempuan.

[4] Bahri, Saiful. "Implementasi Pendidikan KarakterdalamMengatasiKrisis Moral di Sekoah", Ta'allum, Vol. 03. No. 1, Juni 2015.

[5] Bungin, ,Burhan. MetodolgiPenelitaianKuantitatif: Komunikasi, Ekonomi, danKebijakanPublik Serta Ilmu-ilmuSosialLainnya. Jakarta: Kencana, 2005.

[6] Jamroni. Pendidikan KarakterKonsepdanImplementasi. Bandung: Rosdakarya, 2011.

[7] Koentjaraningrat. Metode-metodePenelitian Masyarakat. Jakarta: Gramedia, 1912

[8] Munawaroh. PanduanMemahamiMetodologiPenelitian. Malang: Intimedia.2012.

[9] Lickona, Thomas. Educating for character: How our schools can teach respect and responsibility. New York: Bantam Books, 1991

[10] Nelso, Cary. No University Is an Island, Saving Academic Freedom. NYU Press, 2011.

[11] Purwanto, Ngalim. (2013). Psikologi Pendidikan. Bandung: PT. RemajaRosda Karya.2013.

[12] Sailah, IIIah. Pengembangan Soft Skills di Perguruan Tinggi. Limited Published in DGHE, 2007.

[13] Sugiyono. MetodePenelitianKuantitatif, Kualitatif, dan R\&D. Bandung: Alfabeta, 2014.

[14] Sumanto. MetodologiPenelitianSosialdan Pendidikan. Yogyakarta: Andi Offset. 1990.

[15] Suyanto, Slamet. ImplementasiPendidikan KarakterMelaluiPembelajaranTerpadu.UniversitasNegeri Yogyakarta.

[16] Syah, Muhibbin.“Alternatif Pendidikan Karakter”. 2011,Tersedia di http://padepokanguru.org. 
Correlation of Learning Method of Prophetic Character Education toward Student Achievement Learning Outcomes in Vocational Education in Indonesia

[17] Tilaar. Pendidikan, kebudayaan, danmasyarakatmadani Indonesia. Bandung: PT RemajaRosdakarya, 1999.

[18] Zuriah, Nurul.MetodologiPenelitianSosialdan Pendidikan: Teori-Aplikasi. Jakarta: BumiAksara, 2006.

Citation: Ishomuddin. " Correlation of Learning Method of Prophetic Character Education toward Student Achievement Learning Outcomes in Vocational Education in Indonesia" International Journal of Humanities Social Sciences and Education (IJHSSE), vol 4, no. 11, 2017, pp. 197-207. doi: http://dx.doi.org/10.20431/2349-0381.0411023.

Copyright: (C) 2017 Authors. This is an open-access article distributed under the terms of the Creative Commons Attribution License, which permits unrestricted use, distribution, and reproduction in any medium, provided the original author and source are credited. 